\title{
膝前十字靫帯損傷に合併する骨軟骨病変
}

一 MR 像と鏡視所見の比較一

\author{
鳥取大学整形外科 \\ 縄 田 耕 二・山 本 吉 藏 \\ 豊 島 良太
}

鳥取県立中央病院

鱸俊 朗・山 形 泰 司

\section{Clinical Significance of Bone Bruises and Cartilage Lesions Associated with Anterior Cruciate Ligament Injuries by Magnetic Resonance Imaging and Arthroscopy}

\author{
by \\ Koji Nawata, Kichizo Yamamoto and Ryota Teshima \\ Department of Orthopedic Surgery, \\ Faculty of Medicine, Tottori University \\ Toshiro Suzuki and Taiji Yamagata \\ Department of Orthopedic Surgery, \\ Tottori Chuo Prefectural Hospital
}

In 85 patients with anterior cruciate ligament (ACL) rupture, we examined bone bruises retrospectively using magnetic resonance imaging (MRI). In 53 patients who underwent arthroscopy, the bone bruises were compared with the cartilage lesions. Depending on the time from their ligamentous injury to the performance of MRI, the patients were divided into three groups: the acute group (less than 1 months, $n=29$ ), the subacute group (between 1 and 12 months, $n=29$ ), and the chronic group (12 months or more, $\mathrm{n}=27)$. The detection rate of bone bruises by MRI was significantly higher in the acute group than in the other groups $(p<0.0001)$. Bone bruises were always detected in the same locations of the lateral compartment of the knee joint. In four patients who observed bone bruises in the first MRI and underwent follow-up MRI 3-6 months later, bone bruises had disappeared in the follow-up MRI. In the acute group, bone bruises in the lateral femoral condyle were often found to be accompanied by cartilaginous injuries. In the subacute and chronic groups, the rate of degeneration of these cartilaginous lasions had progressed.

Key words : Bone bruise (骨挫傷), Cartilage lesion (軟骨病変), Anterior cruciate ligament injury（前十字䩲帯損傷）

はじめに

膝前十字勒帯損傷は，受傷時軟骨下骨組織に骨挫傷 （bone bruise）を高頻度に合併することが報告4)5) さ れているが, その臨床的意義は不明である.そこで bone bruise の経時的な変化と, bone bruise と関 節軟骨病変の関係について検討した。

\section{対象および方法}

1989 年より 1994 年の間に膝前十字䩲帯損傷と診断 
された症例の内， MRI 検査を施行した 85 例 85 膝 （男性 40 例，女性 45 例， 12 歳 $~ 58$ 歳平均年齢 26.7 歳）を対象とした。症例を受傷から MRI 撮像までの 期間により, 急性群（～1 カ月）：29 例，悪急性群 (1 力月〜 1 年) : 29 例，慢性群 (1 年〜): 27 例の 3 群 に分け以下の検討を行った。

(1)横断分析：各群における bone bruise の発生部 位と頻度を調査するとともに，画像の量的・質的分析 を行った. (2)縦断分析：Follow-up MRIを撮影し た 4 例について bone bruise の量的 ·質的な推移を 検討した. (3) MR 像と鏡視所見の対比 : 関節鏡を行っ た 53 例について, MR 像と軟骨所見を比較検討した.

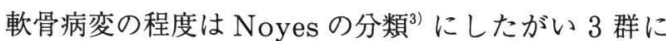
分けた。

MRIの使用機種は, Siemens Magnetome H15, 1.5 テスラおよび島津 MRI, SMT-100, 1.0 テスラで, スピンエコー法を用い $\mathrm{T} 2$ 強調画像とプロトン密度画 像を撮像した。

結

果

\section{1) 横断分析}

Bone bruise は急性群ほど高率に認められ（急性 群 : $79 \%$, 悪急性群 : $55 \%$, 慢性群 : $22 \%$ ), 各群の 発生率には有意の差が認められた（chi-square test, $\mathrm{p}<0.0001)$.また, 慢性群ほど T2 強調画像の信号強

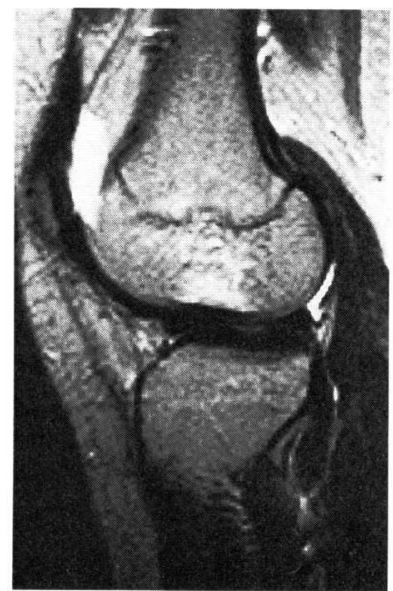

a
度が低下し範囲が縮小していた。 Bone bruiseの発 生部位は大腿骨外側顆と脛骨外側顆がほとんどで，大 腿骨外側顆では terminal sulcusよりやや後方の軟 骨下骨終板から海綿骨部にかけて放射状に認められる ものが多く，脛骨外側顆では後方の軟骨下終板より遠 位の海綿骨部に水平に走る像として認められるものが 多かったままた,脛骨外側顆の bone bruise は亜急 性群, 慢性群では大腿骨外側顆のものと比べ頻度が低 かった（表 1).

\section{2 ) 縦横分析}

Follow-up MRI は受傷後平均 4 力月（3〜6力月） で撮像した。全例とも初回の MR 像で認められた bone bruise は消失していた（図 1).

3 ) MR 像と鏡視所見の対比

大腿骨外側顆の軟骨病変は bone bruise と一致し た部位に認められ，その頻度は約 $50 \%$ で群間に差が 認められなかった。軟骨病変は急性群では亀裂，陥凹 が多く, 亜急性群・慢性群ではその範囲と変性度が増

表 1 Bone bruise の部位

\begin{tabular}{lcccc}
\hline \hline & 急性群 & 垔急性群 & 慢性群 & 計 \\
\hline 大腿骨外側顆 & 21 & 16 & 6 & 43 \\
脛骨外側顆 & 21 & 8 & 1 & 40 \\
大腿骨内側顆 & 0 & 1 & 0 & 1 \\
\hline & \multicolumn{4}{r}{ (Bone bruise を認めた症例 : 45 例) }
\end{tabular}

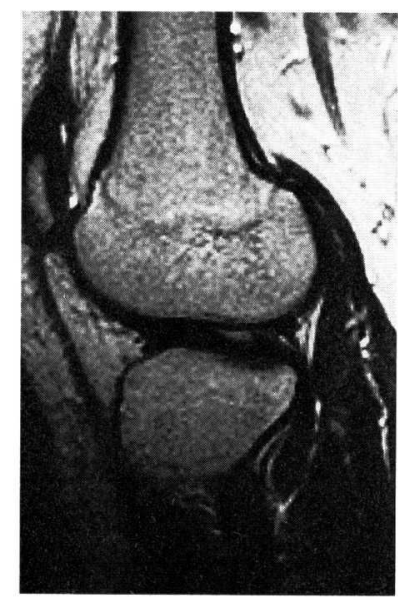

b

図 1 Follow-up MRI (lateral compartment: T2 強調画像 14 才女性 a. 受傷後 11 日 b. 受傷後 3 力月 


\section{大腿骨外側顆}

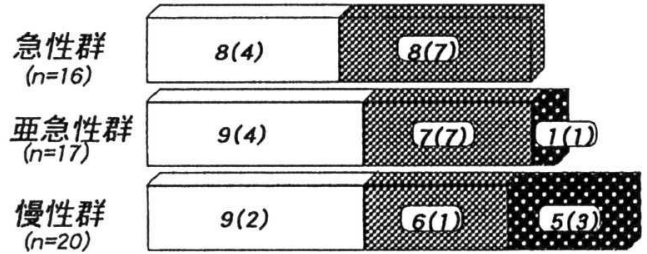

\section{大腿骨内側顆}

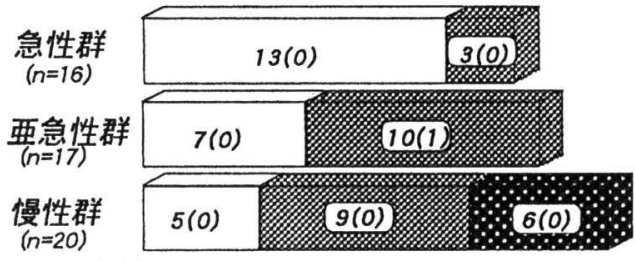

$\square$ Grade 1: Cartilage surface intact

Grade 2: Cartilage surface damaged

Grade 3: Bone exposed (from Noyes, 1989)

(): Bone bruiseを翟めた症例数
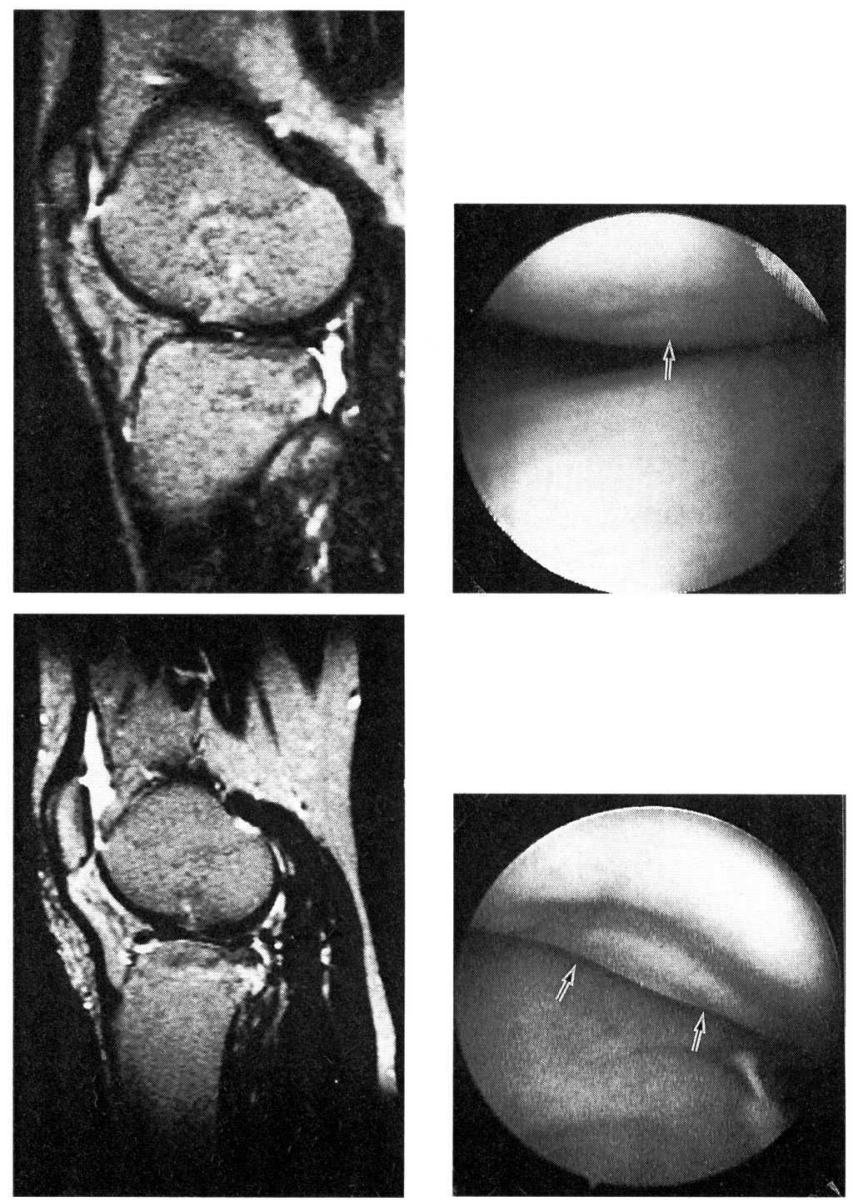

図 3 MR 像と鏡視所見の対比

a. 急性群：16 歳女性（大腿骨外側顆）

b. 慢性群 : 25 歳男性（大腿骨外側顆）

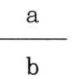


加していた。一方, bone bruise の認められなかっ た大腿骨内側顆の大腿骨内側顆の軟骨病変は急性群に はあまり認められず, 亜急性群, 慢性群となるほど頻 度, 変性度とも増加していた（図 2,3$)$.

\section{考察}

1 ) Bone bruise の経時的変化

近年, 新鮮前十字勒帯損傷例の外側大腿脛骨関節に bone bruise が高頻度に認められることが報告され ている．また，我々は横断分析により bone bruise は靫带損傷受傷時に受傷肢位に関連して発生する損傷で

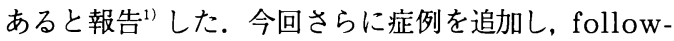
up MRIの分析も加えた結果，やはり，前十字勒帯 損傷に合併する bone bruise は，䩲带損傷受傷時 に発生し，MR 画像上経過とともに範囲が縮小し数 カ月で消失することが判明した。したがって， bone bruise の認められる部位は勒帯損傷受傷時に関節軟 骨から軟骨下骨にかけて強い衝撃が加わった部位を反 映していると考えられる。

2 ) Bone bruise と関節軟骨病変の関係

Noyes $ら^{2)}$ は，関節鏡所見より 新鮮前十字靫帯損 傷例の $20 \%$ の大腿骨外側顆に高度の軟骨損傷を認め たと報告し，靫帯損傷受傷時に同部に加わる衝撃の大 きさを示唆している. Spindler $ら^{6)}$ の報告や，我々 の報告1) では, 大腿骨外側顆の bone bruise に一致 した部位の関節軟骨に，高頻度に軟骨損傷が認められ た、今回，各群における bone bruise と関節鏡所見 を対比検討した結果, 大腿骨外側顆の bone bruise に一致した部位の関節軟骨は，䩗帯損傷受傷時より損 傷を認めるものが多く, 徐々に範囲と変性度が増加し ていた。一方, bone bruiseのあまり認められなかっ た大腿骨内側顆の軟骨病変は, 靶帯損傷受傷時にはあ まり認められず, 不安定膝や半月損傷に起因して二次 的に発生・進行するものが多いと考えられた。

\section{ま と め}

(1)Bone bruise は靫帯損傷受傷時に, 肢位と関連 して発生する一次的損傷であり，受傷時関節軟骨から 軟骨下骨組織にかけて強い衝撃が加わった部位を反映 する.

(2) Bone bruise は MR 画像上経過ともに範囲が縮 小し数力月で消失する.

(3)大腿骨外側顆の bone bruise に一致した部位の 関節軟骨は, 受傷時より損傷を認め, 徐々に範囲と変 性度が増加していた。一方, 大腿骨内側顆の軟骨病変 は, 靱帯損傷受傷時にはあまり認められず, 不安定膝 や半月損傷に起因して二次的に発生・進行するものが 多いと考えられる.

\section{文献}

1) Nawata, K., Teshima, R., Suzuki, T.: Osseous lesions associated with anterior cruciate ligament injuries. Assessment by magnetic resonance imaging at various periods after injuries. Arch. Orthop. Trauma. Surg., $113: 1-4,1993$.

2) Noyes, F.R., et al.: Arthroscopy in acute traumatic hemoarthrosis of the knee. J. Bone Joint Surg., 62-A : 687-696, 1980.

3) Noyes, F.R., et al.: A system for grading articular cartilage lesions at arthroscopy. Am. J. Sports Med., 17 : 505-513, 1989.

4) Rosen, M.A., Jackson, D.W., Berger, P.E.: Occult osseous lesions documented by magnetic resonance imaging associated with anterior cruciate ligament ruptures. Arthroscopy, $7: 45-51,1991$.

5) Speer, K.P., et al.: Osseous injury associated with acute tears of the anterior cruciate ligament. Am. J. Sports Med., $20: 382-389,1992$.

6) Spindler, K.P., et al.: Prospective study of osseous, articular, and meniscal lesions in recent anterior cruciate ligament tears by magnetic resonance imaging and arthroscopy. Am. J. Sports Med., 21 : 551-557, 1993. 